\title{
The production of tourism in Ponta Negra, Northeast Brazil: policies, representations and logics of desire
}

\author{
Octávio Sacramento \\ Department of Economics, Sociology and Management, Centre for Transdisciplinary Development Studies, \\ University of Trás-os-Montes e Alto Douro, Vila Real, Portugal
}

\begin{abstract}
This article discusses how the beach neighbourhood of Ponta Negra (Natal, RN), in the Northeast of Brazil, came to experience the intensive tourist development that now characterises it. Its origins as a fishing village, its gradual emergence as a local resort and the internationalisation of its tourism in the late twentieth century are examined. The discussion of this process demonstrates how public policies have played a major role not only in configuring the model of spatial planning and urbanisation that was adopted, but also in defining Europe as the main geographical focus of tourist internationalisation, in creating attractive conditions for foreign investment, and in the construction and dissemination of a tourist identity largely founded on past images and desires. At the same time, this discussion of Ponta Negra's tourist-capitalist appropriation, Europeanisation and its (re)production as a site of racialised desires contributes to a better understanding of the ambivalent spatialities and multiple tensions that coexist in the neighbourhood today. The analysis presented here draws on empirical data collected during a period of ethnographic fieldwork in which the predominant methodologies included participant observation, semi-structured interviews and documental and statistical research.
\end{abstract}

\section{ARTICLE HISTORY}

Received 5 July 2016

Accepted 21 April 2017

\section{KEYWORDS}

Tourism production; sociospatial changes; public policies; representations; logics of desire; Ponta Negra (Natal; Brazilian Northeast)

\section{Introduction}

The beaches of Natal (capital of the State of Rio Grande do Norte - RN), like those of many other locations in the Northeast of Brazil, have become popular destinations for mass tourism and, in the latter years of the twentieth century, can be considered fully integrated into the circuits of global capitalism (Fonseca \& Lima, 2012). This article discussed the tourism production and internationalisation that has been experienced by the neighbourhood of Ponta Negra (Natal's south zone), which is not only one of the largest and most cosmopolitan beach resorts of $\mathrm{RN}$, but one that most eloquently exemplifies the dynamics of what authors such as Picard (1997), Gmelch (2004) and Carrigan (2011) have referred to as the 'touristification of place, self, and belonging' that has accompanied the ceaseless incorporation of new sites into the so-called 'pleasure periphery' (Turner \& Ash, 1975/ 1991). In particular, we focus on the posture taken by the state in this process, as 
evidenced by its unshakable faith in tourism as the panacea for developing the depressed regions of the Brazilian Northeast (Duda \& Araújo, 2014; Thevenin, 2011).

The discussion below is guided by three main objectives: (1) to map the most relevant aspects of the tourism-based urbanisation and modernisation of Ponta Negra and the production of its identity as a geography of sensuality and passion, intrinsically linked to a (post)colonial 'transatlantic cultural economy of desire' (Veissière, 2011) and symbolically set up by intersecting notions of gender, race, nationality and sexuality, as has been the case in many other destinations of the global tropics (Sacramento, 2016a); (2) to assess the role of public policy in tourism's expansion and the associated capitalist appropriation of place; (3) to understand how the main public bodies in the tourism sector helped to attract major flows of male visitors to Ponta Negra (mainly from Mediterranean Europe) by reclaiming postcolonial images, connections and desires, underpinned by a discourse and iconography reflecting female exoticism and sensuality, thereby inadvertently associating the resort with so-called 'sex tourism'.

The data on which the analysis is based were collected during the preparation of the author's PhD (Sacramento, 2014) on transnational configurations of intimacy between local Brazilian women and European men (gringos) engaging mainly in transactional sex (programas) that were initiated during the latter's tourist visits to Ponta Negra. Fieldwork in this specific location took place over six months, from November 2009 to May 2010. Empirical research emphasised qualitative methodological approaches, with ethnography being the guiding procedure for the collection of information (Sacramento, 2016b). The data that specifically accompany the discussion throughout this text resulted from the combination of different methodological procedures, among which should be highlighted participant observation, involving prolonged and close contact with different social actors (e.g. tourists, residents, hawkers, shopkeepers, politicians and associative agents), generating a large volume of information, systematically recorded in a detailed narrative format in a field diary. At the same time, 50 semi-directed interviews permitted more in-depth and systematised data collection from some informants. In order to frame and complement these denser ethnographic elements, statistical data on tourism in the Natal area were collected and documentary research conducted in the main public bodies with direct responsibilities for municipal and state tourism. This combination of intensive and extensive empirical research allowed the mapping of the major transformations of the neighbourhood over the last 50 years to be to undertaken and the key role of tourism in this process to be assessed.

\section{From fishing village to ambivalent tourist resort}

Until the middle of the twentieth century, Ponta Negra was one of those small fishing villages on the Brazilian coast that would subsequently experience great tourist expansion (Araújo \& Vargas, 2013; Brandão, 2013). With poor access, yet only $10 \mathrm{~km}$ from the city of Natal, the village had remained relatively isolated from and peripheral to the nearby city. Besides their fishing, its inhabitants had around 550 hectares of community lands on which they could cultivate essential crops for the domestic economy (Sá, 2010, p. 114). Lacking formal registration, the majority of these lands, during the 1950s and the 1960s, were illegally appropriated (grilagem) by the private sector and subjected to a large-scale 'institutional theft' perpetrated by three forces - the state, real estate 
businesses and the Catholic church - that subsequently collaborated on the construction of the Barreira do Inferno military complex on part of the land that had been grabbed (Sá, 2010, pp. 114-117). These developments opened the door to a surge in property speculation and urban expansion that, combined with new leisure habits on the part of local elites, came to transform the physiognomy of Ponta Negra. As Souza (in Semurb, 2009, p. 203) has highlighted,

in the middle of the 20th century, the elite from Natal installed themselves at the water's edge, building their summer houses there. In the 1970s, urban expansion in the form of housing estates built away from the coast brought even more people to the neighbourhood.

Thus a beach that had hitherto catered only to the working needs of fishermen and the leisure needs of the local community gradually begins to be appropriated as a leisure site by the most influential sections of Natal society, those who had adopted the national fashion for owning a second residence by building their weekend retreats and summer houses there (Júnior, 1997; Silva \& Fonseca, 2010). In the stage prior to the development of mass tourism, the beach had been discovered by an 'alternative' set of young people '[...] who found in this paradisiacal place, away from the city and with poor access, the very conditions they needed to experiment with sex and drugs, something unacceptable to the dominant political and moral order' (Ribeiro \& Sacramento, 2006, p. 164). With the growth of Ponta Negra as an ecology of leisure and pleasure, many of those born in the village, having been fleeced of their lands, began trying to find new sources of income besides fishing: informally organised activities targeting visitors, such as the production and sale of handicrafts and retail beach stalls (Bezerra \& Sá, 2008, p. 7). This was the beginning of the 'touristification' of the beach and its ever wider and deeper commercial exploitation. Almost from the beginning, this process generated intense social tensions, particularly between street vendors and/or foreign tourists, on the one hand, and the local affluent classes, on the other (Sacramento, 2014). With tourism massification continuing apace, and the progressive stigmatisation of the destination as a meeting place for gringos and garotas de programa, many of the old vacationers, especially those of the privileged classes, began selling their properties and moving to Natal's more exclusive coastal areas, thereby re-establishing both distance and distinctiveness in physical, identity and social terms (Bourdieu, 1979/2007).

During the 1980s, the scale and dynamics of the tourism sector in Natal began to display unmistakable signs of growth, largely as a result of specific policies to promote the sector, and of urban processes designed to meet its main demands, such as the improvement of road connections and the provision of new infrastructure (Furtado, 2008, pp. 57-67). Of all these initiatives, the Parque das Dunas/Via Costeira project is often referred to as the main factor responsible for the city's tourism growth (Cavalcanti, 1993; Costa, 2008; Cruz, 1995; Furtado, 2008; Júnior, 1997; Sá, 2010; Silva, 2003), in particular, the development of tourism towards the south, where Ponta Negra quickly became synonymous with Natal's tourism boom. For about 10 km, the Via Costeira hugs the coastline, passing through the Parque das Dunas protected ecological zone and connecting the city's Areia Preta beach and Ponta Negra. On completion of the road, some of the largest and most prestigious hotels of Natal began to be built, where until then there had been no hotels able to compete in the market for international tourists. Designed in accordance with public policies to promote tourism, this mega-project, coordinated by the former 
Rio Grande do Norte Tourism Promotion and Development Company (Emproturn), was launched in 1979 and opened in 1983, with the aim of acting as the great catalyser of the organisation and development of a mass tourism sector. As Furtado concludes (2008, p. 59), 'from that moment onwards, tourism began to acquire importance in the urban economy and to forcefully assert itself'. In 2016 there were 12 four- and five-star hotels on the Via Costeira, some of them belonging to European hotel chains, such as the Portuguese Pestana Group's Pestana Natal Beach Resort.

Also at the beginning of the 1980s, the Avenue Engenheiro Roberto Freire became a dual carriageway, ensuring a more efficient link between the Via Costeira - Ponta Negra axis and the BR101, main access road to what was, at the time, the Augusto Severo international airport, and providing, in the opposite direction, a better accessibility to the city centre. This avenue quickly became the main axis for Ponta Negra's tourist urbanisation (Furtado, 2008; Júnior, 1997). Those travelling from the city centre have the Parque das Dunas between them and the sea and when they reach the Special Tourist Zone 1 (ZET-1) of Ponta Negra there is a non aedificandi area designed to provide all visitors with an unimpeded view of the beach and of the Morro do Careca sand dune, Natal's most iconic landmark. The towering high-rise apartments (espigões) that cater to Natal's middle class and to visiting tourists, along with other facilities dedicated to residents' and visitors' consumption needs, have all been built on the opposite side of the avenue (see Figure 1). In the same urban landscape there are also impressive houses whose presence is an eloquent testimony to the power of the tourist-related real estate investment (Ferreira, Bentes, \& Clementino, 2006) associated with the expansion of European residential tourism (Clementino, 2009; Silva \& Fonseca, 2010), a category that displays a greater connection to place and has often provided the location for transnational relationships of intimacy to develop (Sacramento, 2014).

The Via Costeira, Avenue Engenheiro Roberto Freire and more recently the Rota do Sol (the southern route that provides a connection to the other south coast beaches)

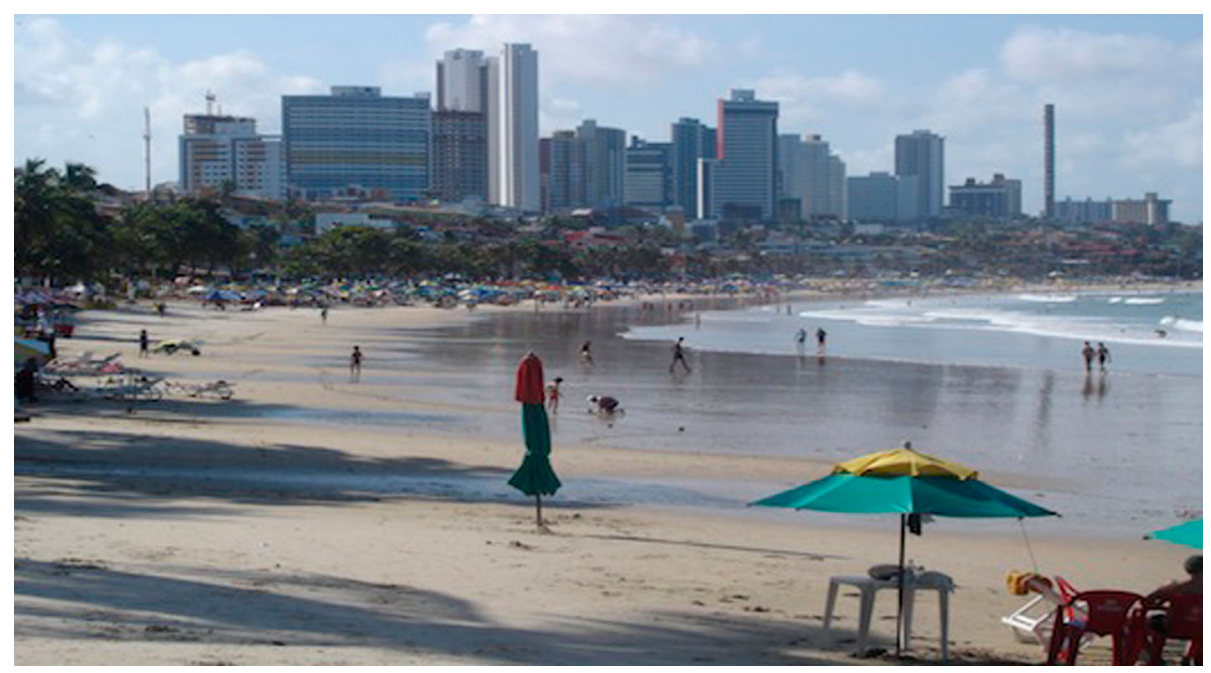

Figure 1. South-north view of the beach at Ponta Negra. Adjoining the beach, the ZET-1. To the rear, the new residential towers (espigões). 
constituted the main axis of Ponta Negra's urban-tourist expansion, allowing the former fishing village to affirm its key role in the development of the Natal metropolitan area. Tourism and the major dynamics of urbanisation - in particular the real estate boom and the vertical growth of the built landscape (Clementino, 2004; Silva, 2003) - advanced inwards towards the city centre (via Avenue Engenheiro Roberto Freire) and outwards to its beaches (through the Via Costeira), edging ever closer to Ponta Negra (Furtado, 2008), making the latter an eminently transnational beach resort and one of the main poles of the region's tourist internationalisation in the last decade of the twentieth century. In the process, its resident population increased significantly, by an average of approximately 2\% annually, from 18,070 inhabitants in 1991 to 24,013 in 2007 (Semurb, 2010, pp. 121, 226). The development of tourism played, directly and indirectly, an important role in this significant demographic growth.

Alongside the progressive incorporation of Ponta Negra into the circuits of mass tourism, the increasingly residential function that it acquired as a result of the construction of housing estates (conjuntos) - attracting mostly middle-class residents - was a structural factor in the expansion of the area's population and growing socio-spatial heterogeneity. Currently, Ponta Negra displays multiple spatialities, in addition to its more touristoriented locations and circuits, of which the beachside area is the prime example. Prominent among and in contrast to Ponta Negra's various other spaces, are (a) the conjuntos that appeared as a result of more recent urbanisation processes; and (b) the old village (vila) which houses the neighbourhood's 'natives' (nativos) a designation covering not only the descendants of the area's original Amerindian, African and Portuguese communities, but also the families who settled there in the late nineteenth century, displaced from neighbouring municipalities affected by serious drought (Souza, 2008). Not only does the grid-plan layout, standardised construction and formal aesthetics of the conjuntos contrast starkly with the spontaneity and sinuosity of the vila's built landscape, but also the class origins, lifestyles and sociabilities of their respective inhabitants. Against a backdrop of scant public investment and the persistence of serious problems of poverty, drugs and violence, the vila's bustling and popular social landscape is the result of both the activities of 'natives' and the presence and cross-cultural contributions made by outsiders. The urban middle-class population of the conjuntos constitute a sociocultural setting that is wholly distinct from that of the vila, bringing together residents from the State of Rio Grande do Norte (norte-riograndenses) and many people from outside (chegantes), including many from other areas of Brazil (predominantly from the South) and others from abroad (Neverovsky, 2005).

Ponta Negra's socio-spatial dissonances make it the focus of numerous disputes, in which the local middle class is inevitably one of the major protagonists (Carrier-Moisan, 2013). This milieu is traversed by numerous tensions between classes and between nationalities, in which international processes of mass tourism often collide with the aspirations of more affluent and conservative sectors of local society and tend to be perceived by them as undermining morality and local identity. The presence of foreign tourists and the fact that they may establish relationships of intimacy with local women creates disquiet among many local natalenses, who interpret this scenario as a new invasion, a sequel to colonial occupation. It is common to hear them claim that Ponta Negra is European (Ponta Negra é dos europeus) and expressing concern ranging from ambiguity to outright hostility with regard to foreigners - a response that has been documented for other 
tourist destinations (Abbink, 2004; Bezerra, 2010; Simoni, 2015). In general, the neighbourhood as a whole is the subject to high levels of stigmatisation: the widely used toponymical pun Puta Negra ('Black Whore') eloquently summarises and evokes the stigma that Ponta Negra now bears. In sum, this coastal neighbourhood has become the focus of a complex intersection of a number of processes; it now constitutes a space that is disputed and, due to the development of tourism, subject to intricate ambivalences. To a large extent, the socio-spatial tensions and disputes are the result of the boundaries of class, race, gender-sexuality and nationality, generated by the tourist-capitalist appropriation of Ponta Negra, the resort's progressive Europeanisation, and its (re)production as a site of racialised desires, moulded by the deeply rooted 'ghosts of empire' (Veissière, 2011).

\section{The decisive stimulus of public policies}

The making of Ponta Negra - and, in general terms, the city of Natal - as a destination for mass tourism, is closely linked to the evolution and impact of state policies (Silva, 2010) and to the varying role of external financing in that process. Furthermore, this intimate connection has contributed to the continual reconfiguration of how people perceive, imagine and evoke tourism in all its dimensions and manifestations. The international projection of tourism in Natal, as elsewhere in the Northeast of Brazil, began in the 1990s, in response to federal policies aimed at making the sector an important axis of regional and national economic growth and development (Duda \& Araújo, 2014; Thevenin, 2011). These policies coincided with an increasing openness of the Brazilian economy to foreign capital and private initiative (Araújo, 1999), underpinned by a shift towards a markedly neoliberal agenda that was ideologically and financially sponsored by the International Monetary Fund (IMF), the International Bank for the Reconstruction and Development (IBRD) and the Inter-American Development Bank (IBD). These institutions, in addition to facilitating additional external funding to an economy already heavily dependent on foreign credit, encouraged the disbursement of ever larger amounts of public resources to create the most attractive local conditions for foreign private investment, whose providers have in turn profited most from public-sector tourism policies (Bursztyn, 2003; Thevenin, 2011).

In the Northeast of Brazil, the Programme for the Development of Tourism (Prodetur) played a particularly important role in the internationalisation of tourism in what is still one of the poorest regions of the country. Through Prodetur, state governments ensured financial support for the type of infrastructural improvements (e.g. improved vehicular access, sewage and electricity supply) that were essential to attract investment from national and foreign business groups (Bursztyn, 2003) able to commit themselves to the development of tourism projects and with the ability to compete in the international market. With dedicated public investment assured, Ponta Negra rapidly developed an extraordinary concentration of tourism accommodation and related services - around 350 units with approximately 18,000 beds (Severo, 2009, p. 31) - often owned and operated by Europeans.

Since 1994, Prodetur initiatives by the RN state government have been decisive in establishing the metropolitan area of Natal as a key leisure destination: visitor numbers almost doubled between 1995 and 2000 from 588,383 to 917,676, leading to substantial growth in tourism's contribution to state-level GDP (Technum Consultoria, 2002, p. 23). By 2009, the annual number of visitors had increased to almost 1.5 million (Setur, RN State 
Secretariat for Tourism, 2010), allowing Natal to join the cities of Salvador, Fortaleza and Recife as one of Northeast Brazil's elite tourist destinations. The municipality of Natal was the main recipient of Prodetur investments: in addition to the Parque das Dunas Via Costeira project (consisting of almost 1200 hectares of Atlantic forest reserve between Ponta Negra and Natal, served by the Avenida Senador Dinarte Mariz coastal expressway) and associated access roads, two other initiatives were decisive in attracting increased tourist flows, especially to the southern parts of the city: the upgrading of Natal's Augusto Severo Airport at Parnamirim, aimed at increasing international air connections, and investment in a wide-ranging urban modernisation project that allowed Ponta Negra's infrastructures to be improved (Fonseca, 2005). In preparation for increased visitor numbers, the authorities controversially made previously undeveloped coastal areas eligible for 'requalification'.

Taking into account the decisive role air transport plays both in stimulating the constant growth of world tourism and in turning more peripheral areas of the globe into mass tourism destinations (Azarya, 2004), the expansion and modernisation of Natal's airport was vital to fulfilling the city's ambition to become a tourism destination on a truly transatlantic scale. In the second half of the 1990s, the total flow of passengers (departures and arrivals) rose $47 \%$ (at a rate of almost $8 \%$ per annum) from 610,844 in 1995 to 899,363 in 2000 (Technum Consultoria, 2002, p. 22). Over the same period, officially licensed international charter flights tripled from one to six, with all the new traffic coming from Europe. During the first decade of the twenty-first century airport traffic continued to intensify, though mainly as a result of growing domestic popularity: from 2005 to 2010 the total number of passengers using the airport almost doubled to just under 2.5 million (Infraero, 2011), while in the same period, international passenger flows decreased by over $50 \%$ from almost 245,000 to just under 118,000 (idem), i.e. the share of international passengers falling from $19 \%$ to $5 \%$. Also, by 2010 , the weekly number of charter flights had fallen from eight to six: two from Portugal, two from Italy, one from Spain and one from the Netherlands. This downward trend in charter flights and international tourist flows, exacerbated both by the European and global economic crisis of 2008-2009 and by local factors (such as growing violence and insecurity, and erosion of Ponta Negra's beach), persisted until 2014, when the Governor Aluízio Alves International Airport was opened in São Gonçalo do Amarante, about $30 \mathrm{~km}$ of Natal (Araújo, Gomes, Freitas, \& Brito, 2016).

Charter flights are often seen not only as a key indicator of the massification of tourism in general, but also the development of so-called 'sex tourism' in particular (Azarya, 2004; Carter \& Clift, 2000). The first such flights to Natal began at the end of 1995, with both the authorities and local stakeholders giving top priority to the establishment of air routes from European countries. A former State Secretary for Tourism (aged 62) provided the following description of the genesis of Europe-Natal flights and how their emergence and organisation may have contributed, from the very beginning, to the marked presence of male Italian tourists in Ponta Negra:

There was a commercial director at Varig [Airlines] that happened to be from Rio Grande do Norte. There was some misunderstanding with the other directors, but he managed to negotiate his way off the board and went to Rome to become Varig's commercial director there. Once there ... well, he was a guy with a vision, a different one from Varig's, and he was the first person to really look at the Northeast of Brazil - just because he was from there. He 
thought that the Northeast could become a tourist destination for the European market, you see, and so he got moving and launched the first direct flight. The route was Milan - Natal Fortaleza. He was the first person to work on the Northeast as a tourist destination. And then the whole thing just kept going. [...] In the early 1990s, in 1992-93, when that flight from Italy to Natal first started [...] it began to attract an enormous flow of Italian men. I remember there was this Italian travel agency that had a lot of clients from the brickmaking and ceramics producing region in the centre of Italy. Now, that region had many clients all of the same type, a specifically male clientele, and so it was that sex tourism was given its first try-out. [...] Afterwards, the regular flight became a charter flight, organised by an agency called Dimensione Turismo, which placed many of the passengers in and around Ponta Negra. Then it all really started .... and it became a much more mass-market thing. A sort of a bubble [bolsão] of sex tourism began grow in the Ponta Negra area. That was at the end of the 1990s.

As stated by this informant, the first weekly charter connection flew between Natal and Milan. On its official web site, the Italian travel agency Dimensione Turismo describes Natal as a turning point for the company's rise in the Italian market: 'Brazil was the destination that started our company more than twenty years ago, but it was the "discovery" of Natal in particular that allowed us to assert ourselves in the Italian tourist market, and to assume a leadership position' (www.dimensioneturismo.it). Referring to its establishment of the very first charter flight, it goes as far as to describe itself as a major contributor to local tourism development: 'By launching this brave charter operation that has now been operating for 10 years, we made a significant contribution to tourist development in this beach resort, strong in our belief that it had the potential to receive [our tourists]' (idem). Since 2003, the agency has also been the owner of a major hotel unit (near the Morro do Careca at the southern end of the Ponta Negra beach), whose clients are almost exclusively tourists from Italy. Its pioneering role seems to have acted as a catalyst for a wider Italian presence in Ponta Negra and as a key example of the opening of a North-eastern Brazilian resort to European tourists.

Along with the effects of building tourist-related infrastructures and securing air connections, the impressive growth of tourism in Natal was also driven by the RN state government's marketing policies for its capital city (Fonseca, 2005; Santos, 2010) implemented by Setur and its affiliate Emprotur in collaboration with local political authorities such as the Municipal Secretariat for Tourism and Economic Development (Seturde). The main foci of this marketing strategy were the domestic, neighbouring South American and European markets, in the latter case Italy, Portugal, Spain, the Netherlands and Sweden. Prominent among the first initiatives to transnationally publicise Natal as a holiday in the 1990s were the numerous promotional events organised in travel agents' own countries (in particular, Italy), including the financing of TV commercials and publicity campaigns in magazines owned by the Abril publishing house (e.g. Veja and Playboy), along with roadshows for travel operators in Rome, Milan, Turin, Bologna, Mestre, Naples and Firenze (Emproturn, 1994).

Since then, marketing efforts have intensified, with Natal's official entities ever-present at major international tourism fairs (mainly in Europe) and significant investment being made in publicity using new information technology and the social media. These and other initiatives aimed at promoting the destination seem to have pursued three main aims: to take advantage of the growth potential of domestic tourism; to consolidate already established international tourism flows from the Mediterranean, Scandinavia and Argentina and to stimulate new tourist flows from countries such as Germany, Chile, France and Russia. 


\section{Recreating old images and logics of desire}

In the construction of a tourist identity for Natal, the local authorities adhered fairly closely to the strategic framework provided by the Brazilian Tourism Company/Brazilian Tourism Institute (Embratur). This federal institution has been a core reference point for all Brazilian tourism promotion, having contributed from as far back as the end of the 1960 s to disseminating an image of Brazil as an exotic and sensual destination, dominated by images of the Carnival, of endless beaches full of mulatas in bikinis, which quickly became the dominant discourse of the marketing efforts by most public and private tourism entities (Alfonso, 2006). The central referent of this discourse was the corporeality of women of mixed-race (mulatas), intensely sexualised through the mainly discursive mechanisms of colonial biopower (Gomes, 2010; Ribeiro \& Sacramento, 2009; Sacramento \& Ribeiro, 2013), and transformed into an icon of a postcolonial nation whose ambition it was to project essentially mestizo characteristics as the principal component of its identity. However, what Embratur created - neither a national identity, nor transnational desires - was nothing substantially new: since its discovery, Brazil's geography has been mapped by various 'myths of origin' structured around an allegedly extraordinary sexuality (Parker, 1991) that became a prime object of European desire (Sacramento, 2015a).

Indeed, rather than a 'maker of images for the Brazilian nation', as Alfonso (2006) has tended to portray it, Embratur was merely the amplifier of pre-existing elements of identity. At the semiotic level, this public company produced and operationalised a plan for tourism expansion that proceeded on the basis of cultural content that was already circulating in various fields of Brazilian society, notably the arts. As Gomes (2010) rightly stresses, when Embratur represented Brazil as 'a paradise of mulatas', it was only reaffirming a version of Brazilian identity that was rooted in Gilberto Freyre's notions of the links between mestiçagem and sexuality, to which were added a few elements drawn from the colonial imagination in which the whole of Latin America constituted a kind of terrestrial paradise. In this regard, my interpretation is in line with that of Blanchette and Silva (2010), namely that it would be naïve and exaggerated to conclude - as Bem (2005) and Alfonso (2006) have done - that the popular association of Brazil with sexuality and the country's subsequent inclusion in international 'sex tourism' routes were essentially due to Embratur's marketing efforts. Although promotional campaigns may have contributed to this result, many other 'structural and ideological factors' should be taken into consideration (Blanchette \& Silva, 2010), including the deep historical roots of the 'erotisation' of Brazil, and the multiple actors and agents that contributed to the international projection of 'Brazilianness' as a particular and particularly potent form of sensuality.

Rio de Janeiro was the first and main incubator of a style of tourism marketing in which, against the backdrop of transatlantic colonial empires, multiple intersections between gender, race and sexuality were to be generated (Stolke, 2006). In 1982, the promotional magazine Rio, Samba e Carnaval - whose very title eloquently evokes the marketing focus identified above, and in which images of mulatas were an ever-present feature - portrayed the metrópole carioca in the following terms: 'The city [of Rio], like a virgin disturbed by her own desire, goes crazy, goes wild with pleasure, euphoria and folly, in a roller-coaster ride of joy, suffering, and ecstasy' (in Alfonso, 2006, p. 122). During the 1980s and 1990s, influenced to a greater or lesser extent by Embratur, the sexualised advertising of leisure 
destinations spread from Rio, the 'city of marvels' (cidade maravilhosa), along the coast to myriad beach resorts, not least of all those located in the Brazilian Northeast. In the specific case of Natal, its incarnation as a 'city of pleasure' may have begun, albeit timidly, with the American military presence during the Second World War, attaining - even before the arrival of mass tourism - its most iconic expression in the gaudy advertising hoardings of the Tahity Motel:

When, in the second half of the 1980s, the Tahity Motel entered into decline and its aggressive publicity disappeared from the streets of the city, the discursive matrix that presented Natal as the city of pleasure had already been incorporated into the lexicon of the advertising people, administrators and entrepreneurs of the tourism sector. The publicity that promoted the city, even material sponsored by official organs, conjured up the traditional images of sand dunes, azure seas and female bodies. (Júnior, 1997, p. 183)

The iconography of the 'global beach' (Löfgren, 1999) and, in particular, the four 'S's' (sun, sea, sand and sex) designated by Crick (1989), appear to have provided the first symbolic coordinates both for the discourse and for the formatting practices that accompanied Natal's simultaneous transformation into a 'leisure product' and its incorporation into the global geography of pleasure and passion. Local initiatives often sought to reproduce much of what was being done in Rio de Janeiro, the great reference point for the internationalisation of Brazilian tourism. In particular, Natal's tourist trade saw the Copacabana beach, the best-known and most iconic part of the carioca coastline, as an example to be followed. Indeed, the publically funded Parque das Dunas/Via Costeira project that was undoubtedly the key factor in tourism expansion in the city (in general) and in the area around Ponta Negra (in particular) had the explicit ambition of creating something akin to Copacabana in Natal. Such mimicry operated on different levels and involved various agents, ranging from politico-governmental entities to private enterprises.

Echoing what had happened at national level, the language used to promote Natal's tourist identity, albeit perhaps not intentionally, nevertheless reflected the dominant values of white heterosexual masculinity that Pritchard and Morgan (2000) have associated with the 'male gaze' in gendered tourism landscapes. Often, the language used reflected an earlier 'cultural logic of desire' (Constable, 2003) that had been forged as part of the colonial and postcolonial political economy, and in which the white western male's erotic and sexual fascination for the mestizo women of the tropics (and, allegedly, vice-versa) is taken as an axiomatic principle. In the specific case of Natal, where the presence of the black and mestizo population is less marked, the racial variable has been employed less in the sexualisation of tourism promotion, compared to Bahia, for example (Williams, 2013). Nevertheless, it should be noted that, seen from an international perspective, Brazilian nationality, femininity and morenidade ('brownness', being more an ideological than a phenotypical concept) constitute three inseparable dimensions of an intensely sexualised stereotype. As Piscitelli (2008, p. 269) has emphasised, 'The epithet [mestiza] is attributed [to Brazilian women] more because of their nationality than the colour of their skin. And this racialisation is sexualised'. Thus nationality has become charged with a multi-layered symbolic equivalence between being Brazilian, being mixed-race and being sensual - regardless of any observable physical characteristics of the women in question.

As mentioned above, in the marketing initiatives and the establishment of charter connections that accompanied Natal's tourist internationalisation, the geographical priorities 
of centuries-old desires and (inter)cultural links were deployed, with special attention being given to Europe, the cradle of the former colonial power. Indeed, Quiroga's comment (in Altman, 2001, p. 41) regarding Cuba, another former colony in the Americas, applies equally well to Brazil in its international context: '[it] has always been linked to the outside world by the threads of desire'.

With the benefit of hindsight, many of Natal's political stakeholders may now hold past strategies of tourist development largely responsible for attracting flows of visitors with profiles now considered 'undesirable'. Allegedly, at the present moment, the main concern of these same stakeholders is to refashion the city's image, in the hope and expectation of promoting a style of tourism that will attract families from elsewhere in Brazil, rather than single foreigners, as can be inferred from the words of Tertuliano Pinheiro, the Secretary of Seturde for the municipality of Natal:

I think those in power were so concerned to attract tourists that they ended up being too little concerned about the quality of the tourists who came. So we started receiving the kind of visitor that we were not interested in, those that travel alone and who are only interested in women. Only now do we understand this, having identified the problem and begun trying to reorganise [...]. We are shifting our efforts to the domestic market, to the Brazilian family that wants to come to visit Natal. (Turismo - Novo Jornal, 2011, pp. 15-16)

In this magazine interview, an implicit moral assessment is made based on a quite specific definition of which tourists are 'undesirable' (i.e. foreign males whose holidays are not organised in a family group) and which are 'desirable' ones (nationals, especially those vacationing as a family) and, in doing so, they presuppose that the prostitution that exists in Ponta Negra is due exclusively to the presence of foreign males (gringos). At the same time, the interview presents an idealised vision of 'desirable' tourism, replete with the normative values that underpin (hetero)sexual family-based morality, and reflecting class-based interests, lifestyle aspirations and moral imperatives from which Ponta Negra's gringos, garotas de programa and informal vendors have been expunged. In a context and conjuncture strongly marked by the moral panic linked to 'sex tourism', this vision is well placed to validate and assert itself, thereby helping to boost certain strategies that, while ostensibly designed to fight the phenomenon, in essence may be driven more by unalloyed economic interests, and by the wish of certain tourism stakeholders to strategically reposition themselves in the market. At a time of declining international tourism to Natal and on the back of already increasing family-based tourism and national visitor numbers, it may be politically opportune for the authorities to help create the conditions they consider most in line with current trends in demand.

Over the last 15 years of tourism expansion, so-called 'sex tourism' has been socially configured as one of Brazil's greatest problems and one of the most resistant stains on its image. Government bodies at federal and state level with the strongest links to the sector, along with other public and private entities, have sought to address what they see as the root of this problem: the promotional semiotics of the 'tourist product'. On a federal level, there is the Aquarela programme, created in 2003, through which Embratur promotes Brazil internationally as a multifaceted destination, by producing new images of the country and departing from its more stereotyped representations. For example, at the state level, as has been the case for some time in RN, laws have been introduced forbidding the use of female erotic images by any leisure destinations in their official marketing 
campaigns, though these images have not completely disappeared from the tourist trade. The aim is to alter an international representation of Brazil that has long been closely linked to exoticism, sensuality and sexuality (Padilla, 2007; Ribeiro \& Sacramento, 2009; Sacramento \& Ribeiro, 2013), a representation that, according to Bignami (2002), has a number of dimensions, including Brazil as 'the land of carnival', as a 'paradise', as 'the home of exoticism and mysticism' and as 'the land of easy sex'. Given that these representations overlap, extend well beyond the field of tourism, and are rooted in well-consolidated elements of national identity, it seems unlikely that mere changes in tourist marketing will have a significant impact on the hegemonic model and imagery that supports the way Brazil is seen by outsiders.

Brazil, as in the case of many other countries now commonly identified as destinations for sex tourism, was first registered on what we may call the world map of desire, at the time of colonisation. As Bishop and Robinson (1998, p. 14) conclude, 'the maps that chart trajectories of power, desire and consumption of the world's resources in the postcolonial world bear a striking resemblance to the earlier maps of the colonial world, whether drawn in Europe, the United States or Japan'. The intensification of globalisation in the latter decades of the twentieth century - particularly visible in the growing flows of international tourists and migrants - undoubtedly widened the scope of these ancient routes of desire and increased the traffic on them. As the number of travellers grew, so did the number and variety of local contexts involved. Ponta Negra and many other tourist sites in the Brazilian Northeast are a product of this process. In part, the emergence of new sites in which the transnationalisation of intimacy could occur can be explained by the declining attractiveness and competitiveness of already established destinations (such as Thailand and the Philippines) where 'sex tourism' had reached saturation point, and which were being abandoned due to their over-commercialised character and lack of 'authenticity' (Piscitelli, 2004).

However, in 'sex tourism' as in so many other endeavours, novelty has proven to be no guarantee of sustainable success: over the years, Ponta Negra's attractiveness and tourist expansion experienced great volatility and began to lose the hegemony it had once enjoyed as Natal's main international tourist destination. Seen against the backdrop of the multiple impacts of the 2014 Football World Cup mega-event (Silva, 2015) and the social, environmental and infrastructural problems that have increasingly plagued Ponta Negra in general and its coastline in particular (Araújo et al., 2016), beach resorts such as Praia do Forte began to gain increasing popularity and now play a prominent role in the tourism centred on the municipality of Natal.

\section{Conclusion}

Through their policy interventions on a federal, state and municipal level, Brazilian public and governmental institutions played an important role in the integration of Natal into the circuits of mass tourism and the structures of global capitalism, and in the Ponta Negra emergence as a favoured destination for the European males who constitute the main 'passion-driven' tourist flows. During the final decades of the twentieth century, it was primarily public entities that boosted tourist development in the Brazilian Northeast by establishing the guidelines for territorial planning, and by providing an urbanisation model that would allow appropriately endowed neighbourhoods to be 
transformed into tourist sites. Furthermore, public bodies created the conditions that attracted large European investments and that defined the Old Continent as the privileged geographical marketing target for the 'internationalisation of place'. Furthermore, the very same public bodies contributed to the reproduction of colonial and postcolonial representations of gender, race, sexuality and nationality in the discourse of tourism promotion, combining them into an eroticised feature that became intrinsic to the supply of tourist services and which promoted - albeit unintentionally it would seem - the incorporation of new destinations into gender-specific and sexualised tourism circuits. Currently, attempts are being made to reverse the process, and to reduce or even eliminate the connotation with 'sex tourism'; it is believed that such steps would calm the moral panic that recent trends have caused, meet the expectations of the local middle-class elite and attract a more 'desirable' kind of tourist - the 'family tourist' to Ponta Negra.

The public policies that boosted the production of Ponta Negra as a tourist destination, by focusing on the creation of conditions that would attract private investment and permit the 'capitalist appropriation of place', have shown scant regard for the local community, either in terms of encouraging its participation in decision-making, or of assuring the sustainability of the development process. As a result, a profound reconfiguration of the lifestyles of the local population has ensued, and new asymmetries and forms of social exclusion have emerged (Silva \& Gomes, 2004), generated by a model of tourism that has shown itself unable to promote a general and balanced distribution of the economic benefits of tourism and related activities. In Brazil, it is women who are more likely to suffer personal and social vulnerability, since they are disproportionately affected by unemployment, precarious employment and low incomes (Lavinas, 1996). Consequently, conventional prostitution and/or the formation of long-term attachments with foreign visitors have come to be counted by many women among the very few opportunities available to them to share in the material benefits tourism provides. However, in this kind of scenarios of intimacy transnationalization there is no unique gender/nationality pattern of 'passionate involvements' between locals and foreign tourists (Cantalice, 2016; Mitchell, 2011), and the development of such liaisons is often associated with the confluence of interests and expectations that transcend the purely economic (Carrier-Moisan, 2015; Piscitelli, Assis, \& Olivar, 2011; Sacramento, 2015b; Williams, 2013).

Large sections of Natal's political establishment and local society today see the proliferation of transnational relationships of intimacy - whose emergence can to some extent be attributed to past strategies that aimed to make Ponta Negra an international leisure destination - as the consequence of a tourism model that needs to be abandoned and the associated stigma to be erased. Ostensibly, a leisure sector dominated in recent times by the so-called sex tourism will be replaced by more sustainable and socially responsible forms of tourism. Though some sort of elite consensus on tourism development may currently prevail, it should be remembered that, from the very beginning, many of the complexities, contradictions and volatilities that manifested themselves as Ponta Negra has evolved from fishing village to tourist destination, can only be understood in the light of much more deeply rooted ambivalences and disputes not only over material and moral issues, but also over questions of the past, present and future identity of the locality and its population. 


\section{Acknowledgements}

I am grateful to Filomena Morais and to Chris Gerry, respectively, for translating and correcting the original text. Finally, I would like to thank the anonymous reviewer whose comments and suggestions contributed significantly to the improvement of successive versions of this article.

\section{Disclosure statement}

No potential conflict of interest was reported by the author.

\section{Funding}

This work was supported by: (1) FEDER European Structural and Investment Funds, through its Operational Competitiveness and Internationalization Programme (COMPETE 2020) [Project $\mathrm{N}^{\circ} .006971$ (UID/SOC/04011); Funding reference: POCI-01-0145-FEDER-006971]; and (2) national funds, provided to Project UID/SOC/04011/2013 through the Portuguese Foundation for Science \& Technology (FCT). The field research reported on here was supported by an FCT doctoral scholarship (SFRH/BD/60862/ 2009).

\section{ORCID}

Octávio Sacramento (i) http://orcid.org/0000-0001-8533-3653

\section{References}

Abbink, J. (2004). Tourism and its discontents: Suri-tourist encounters in Ethiopia. In S. Gmelch (Ed.), Tourists and tourism: A reader (pp. 267-287). Long Grove, IL: Waveland Press.

Alfonso, L. (2006). Embratur: Formadora de imagens da nação brasileira (Masters dissertation). Unicamp, Campinas.

Altman, D. (2001). Global sex. Chicago: The University of Chicago Press.

Araújo, C., \& Vargas, H. (2013). Sorria: você está na Bahia. A urbanização e a turistificação do litoral baiano. Revista de Geografia e Ordenamento do Território, 1(June), 23-41.

Araújo, M., Gomes, H., Freitas, J., \& Brito, M. (2016). O turismo potiguar que chegou a perder 100 mil desembarques!. Revista Brasileira de Pesquisa em Turismo, 10(3), 594-614.

Araújo, T. (1999). Brasil nos anos noventa: Opções estratégicas e dinâmica regional. Revista Brasileira de Estudos Urbanos e Regionais, 2, 9-24.

Azarya, V. (2004). Globalization and international tourism in developing countries: Marginality as a commercial commodity. Current Sociology, 52(6), 949-967.

Bem, A. (2005). A dialética do turismo sexual. Campinas: Papirus.

Bezerra, K., \& Sá, R. (2008, June 27-28). Urbanização e turismo em Ponta Negra: Transformações espaciais na cidade de Natal-RN. V Seminário de Pesquisa em Turismo do MERCOSUL, Universidade de Caxias do Sul, Rio Grande do Sul. Retrieved January 24, 2016, from http://www.ucs.br/ucs/ tpIVSeminTur\%20/posgraduacao/strictosensu/turismo/seminarios/semin_tur/trabalhos/arquivos/ gt14-05.pdf

Bezerra, R. (2010). 'Gringos e nativas': Representações do turista estrangeiro e suas acompanhantes no bairro Praia de Iracema na cidade de Fortaleza (Ceará-Brasil). In M. C. Silva \& F. B. Ribeiro (Eds.), Mulheres da vida, mulheres com vida: Prostituição, estado e políticas (pp. 205-220). Famalicão: Húmus.

Bignami, R. (2002). A imagem do Brasil no turismo. São Paulo: Aleph.

Bishop, R., \& Robinson, L. (1998). Night market: Sexual cultures and the Thai economic miracle. London: Routledge.

Blanchette, T., \& Silva, A. (2010). 'A mistura clássica': Miscigenação e o apelo do Rio de Janeiro como destino para o turismo sexual. Bagoas, 4(5), 221-244.

Bourdieu, P. (1979/2007). A distinção: Crítica social do julgamento. Porto Alegre: Zouk. 
Brandão, P. (2013). Paraísos sob controle: Indícios de reclusão e contenção territoriais pela prática turística no litoral sul de Pernambuco (Brasil). Movimentos Sociais \& Dinâmicas Espaciais, 2(2), 121-137.

Bursztyn, I. (2003). A influência do ideário neoliberal na formulação de políticas públicas de turismo no Brasil. Caderno Virtual de Turismo, 3(4), 7-12.

Cantalice, T. (2016). Dando um banho de carinho! Os caça gringas e as interações afetivo-sexuais em contexto de viagens turísticas, Pipa/RN. Jundiaí: Paco Editorial.

Carrier-Moisan, M. -E. (2013). Saving women? Awkward alliances in the public spaces of sex tourism. In L. Phillips \& S. Cole (Eds.), Contesting publics: Feminism, activism, ethnography (pp. 48-75). London: Pluto Press.

Carrier-Moisan, M. -E. (2015). 'Putting femininity to work': Negotiating hypersexuality and respectability in sex tourism, Brazil. Sexualities, 18(4), 499-518.

Carrigan, A. (2011). Postcolonial tourism: Literature, culture, and environment. New York, NY: Routledge.

Carter, S., \& Clift, S. (2000). Tourism, international travel and sex: Themes and research. In S. Clift \& S. Carter (Eds.), Tourism and sex: Culture, commerce and coercion (pp. 1-19). London: Pinter.

Cavalcanti, K. (1993). Estado e política de turismo: O caso da Via Costeira da cidade do Natal (Masters Dissertation). UFRN, Natal.

Clementino, L. (2004). Os novos empreendimentos imobiliários em Ponta Negra. Natal: UFRN.

Clementino, M. (2009). Turismo de segunda residência: Europeus no Nordeste do Brasil. Retrieved December 17, 2011, from http://www.cchla.ufrn.br/dpp/ppeur/semestres/semestres\%20anteriores/ semestre-011_1/2011_1_disciplinas/tópico_especiais_III/downloads_turismo_cidade/TURISMO\% 20DE\%202a\%20RESIDẾNCIA.pdf

Constable, N. (2003). Pen pals, virtual ethnography, and 'mail order' marriages: Romance on a global stage. Berkeley: University of California Press.

Costa, J. (2008). Políticas públicas, turismo e emprego no litoral Potiguar. Caderno Virtual de Turismo, 8 (2), 115-129.

Crick, M. (1989). Representations of international tourism in the social sciences: Sun, sex, sights, savings, and servility. Annual Review of Anthropology, 18, 307-344.

Cruz, R. (1995). Turismo e impacto em ambientes costeiros: Projeto Parque das Dunas/Via Costeira, Natal (RN) (Masters dissertation). USP, São Paulo.

Duda, J., \& Araújo, L. (2014). Pólos de turismo no Nordeste do Brasil: Crescimento, desenvolvimento e escassez de conhecimento. Caderno Virtual de Turismo, 14(3), 204-218.

Emproturn. (1994). Relatório de ação - 1992/1993. Natal: Emproturn.

Ferreira, A., Bentes, D., \& Clementino, M. (2006). Novas tipologias habitacionais perante a expansão do capital turístico-imobiliário em Natal, RN. Cadernos Metrópole, 16, 141-162.

Fonseca, M. (2005). Espaço, políticas de turismo e competitividade. Natal: EDUFRN.

Fonseca, M., \& Lima, R. (2012). Globalização, turismo e lazer na região metropolitana de Natal/RN. Revista Turismo, Visão e Ação, 14(3), 322-336.

Furtado, E. (2008). A onda do turismo na cidade do sol: Reconfiguração urbana de Natal. Natal: EDUFRN.

Gmelch, S. (Ed.). (2004). Tourists and tourism: A reader. Long Grove, IL: Waveland Press.

Gomes, M. (2010). A (des)(re)construção do Brasil como um paraíso de mulatas. Revista Eletrônica de Turismo Cultural, 4(2), 48-70.

Infraero. (2011). Estatística dos aeroportos. Retrieved December 21, 2011, from http://www.infraero. gov.br/index.php/br/estatistica-dos-aeroportos.html

Júnior, E. (1997). A construção social da cidade do prazer: Urbanização turística, cultura e meio ambiente em Natal (RN) (PhD thesis). Unicamp, Campinas.

Lavinas, L. (1996). As mulheres no universo da pobreza: O caso brasileiro. Estudos Feministas, 4(2), 464-479.

Löfgren, O. (1999). On holiday: A history of vacationing. Berkley: University of California Press.

Mitchell, G. (2011). Turboconsumers in paradise: Tourism, civil rights, and Brazil's gay sex industry. American Ethnologist, 38(4), 666-682.

Neverovsky, C. (2005). De Gata Borralheira a Cinderela: Nova espacialidade decorrente do desenvolvimento turístico, diferenciada pelo estilo de vida em Ponta Negra, Natal, RN (Masters dissertation). UFRN, Natal. 
Padilla, B. (2007). Brasileras en Portugal: De la transformación de las diversas identidades a la exotización. Amérique Latine: Histoire \& Mémoire, 14. Retrieved March 23, 2011, from http:// alhim.revues.org/2022

Parker, R. (1991). Bodies, pleasures and passions: Sexual culture in contemporary Brazil. Boston, MA: Beacon Press.

Picard, M. (1997). Cultural tourism, nation-building, and regional culture: The making of a Balinese identity. In M. Picard \& R. Wood (Eds.), Tourism, ethnicity \& the state in Asian \& Pacific societies (pp. 181-214). Honolulu: University of Hawai'i.

Piscitelli, A. (2004). El tráfico del deseo: Interseccionalidades no marco do turismo sexual no Nordeste do Brasil. Quaderns-e, 4, 1-15.

Piscitelli, A. (2008). Interseccionalidades, categorias de articulação e experiências de migrantes brasileiras. Sociedade e Cultura, 11(2), 263-274.

Piscitelli, A., Assis, G., \& Olivar, J. (2011). Gênero, sexo, amor e dinheiro: Mobilidades transnacionais envolvendo o Brasil. Campinas: Unicamp/Pagu.

Pritchard, A., \& Morgan, N. (2000). Privileging the male gaze: Gendered tourism landscape. Annals of Tourism Research, 27(4), 884-905.

Ribeiro, F. B., \& Sacramento, O. (2006). Sexo, amor e interesse entre gringos e garotas em Natal. Cronos - Revista do Programa de Pós-Graduação em Ciências Sociais da UFRN, 7(1), 161-172.

Ribeiro, F. B., \& Sacramento, O. (2009). Imagens, erotismo e culturas on the road: Perspectivas sobre o Brasil como destino turístico. Configurações, 5-6, 241-255.

Sacramento, O. (2014). Atlântico passional: Mobilidades e configurações transnacionais de intimidade euro-brasileiras (PhD thesis). ISCTE-IUL, Lisbon.

Sacramento, O. (2015a). From Europe with passion: Frameworks of the touristic male desire of Ponta Negra, in the North-East of Brazil. Current Issues in Tourism. doi:10.1080/13683500.2015.1056517.

Sacramento, O. (2015b). Vida boa e história de amor: Desígnios femininos ante turistas europeus no nordeste brasileiro. In Ó. Fernández (Ed.), Mujeres en riesgo de exclusión social: Una perspectiva transnacional (pp. 123-135). Madrid: McGraw-Hill.

Sacramento, O. (2016a). Turismo e transnacionalização da intimidade nos trópicos globais. Revista Turismo em Análise, 27(2), 256-273.

Sacramento, O. (2016b). Localizações e itinerâncias: crónica de um trabalho de campo transatlântico. In H. Martins \& P. Mendes (Eds.), Trabalho de campo: Envolvimento e experiências em antropologia (pp. 179-199). Lisbon: ICS.

Sacramento, O., \& Ribeiro, F. B. (2013). Trópicos sensuais: A construção do Brasil como geografia desejada. Bagoas, 10, 215-232.

Santos, T. (2010). O City marketing em Natal/RN e a construção da imagem da cidade (Masters dissertation). UFRN, Natal.

Sá, K. (2010). Urbanização turística em Ponta Negra: Relações de força e processos sociais no período de 1979-2009 (Masters dissertation). UFRN, Natal.

Semurb. (2009). Natal: Meu bairro, minha cidade. Natal: Prefeitura do Natal.

Semurb. (2010). Anuário Natal 2010. Natal: Prefeitura do Natal.

Setur. (2010). Indicadores básicos do turismo, Rio Grande do Norte - 2002-2009. Natal: Governo do Estado do Rio Grande do Norte.

Severo, M. (2009). Ponta Negra abriga a maior concentração de hotéis. Revista Fácil Nordeste, 97, 3031.

Silva, A. (Ed.). (2015). Metropolização e megaeventos: Impactos da Copa do Mundo 2014 em Natal-RN. Natal: EDUFRN.

Silva, K. (2010). Políticas públicas e a promoção do turismo no Rio Grande do Norte. Revista Mercator, 9(18), 71-79.

Silva, K., \& Fonseca, M. (2010). A produção de residência secundária no litoral oriental Potiguar turismo e capital imobiliário. Caderno Virtual de Turismo, 10(1), 50-63.

Silva, M. C. (2003). Video tours. Etnográfica, 7(2), 451-458.

Silva, M., \& Gomes, R. (2004). Nas contradições do 'belo'. A exclusão social no turismo: Um olhar sobre Ponta Negra. Mercator: Revista de Geografia da UFC, 3(5), 57-66.

Simoni, V. (2015). Tourism and informal encounters in Cuba. New York, NY: Berghahn. 
Souza, I. (2008). Nova história de Natal. Natal: Departamento Estadual de Imprensa.

Stolke, V. (2006). O enigma das intersecções: Classe, 'raça', sexo, sexualidade. A formação dos impérios transatlânticos do século XVI ao XIX. Revista Estudos Feministas, 14(1), 15-42.

Technum Consultoria. (2002). Avaliação do PRODETUR I - RN. Plano de Desenvolvimento Integrado do Turismo Sustentável do Pólo Costa das Dunas. Retrieved July 29, 2011, from http://www.iadb.org/ regions/re1/br/br0323/pditrn1.pdf

Thevenin, J. (2011). O turismo e suas políticas públicas sob a lógica do capital. Caderno Virtual de Turismo, 11(1), 122-133.

Turismo - Novo Jornal. (2011). Ponta Negra: Encantadora esquina do mundo. ano I, 1, 13 May, 14-20. Turner, L., \& Ash, G. (1975/1991). La horda dorada. Madrid: Endymion.

Veissière, S. (2011). Ghosts of empire: Sex, mobility, and violence in the transatlantic cultural economy of desire. Berlim: LIT Verlag.

Williams, E. (2013). Sex tourism in Bahia: Ambiguous entanglements. Champaign: University of Illinois Press. 